\title{
Depression, stress and anxiety in medical students: A cross- -sectional comparison between students from different semesters
}

\author{
Ivana lúcia Damásio Moutinho ${ }^{1}$, Natalia de Castro Pecci Maddalena ${ }^{1}$, Ronald Kleinsorge Roland ${ }^{1}$, Alessandra lamas \\ Granero lucchetti ${ }^{1}$, Sandra Helena Cerrato Tibiriçấ ${ }^{1}$, Oscarina da Silva Ezequiel ${ }^{1}$, Giancarlo Lucchetti $^{1 *}$
}

${ }^{1}$ Núcleo de Apoio às Práticas Educativas, Faculdade de Medicina, Universidade Federal de Juiz de Fora, Juiz de Fora, MG, Brazil

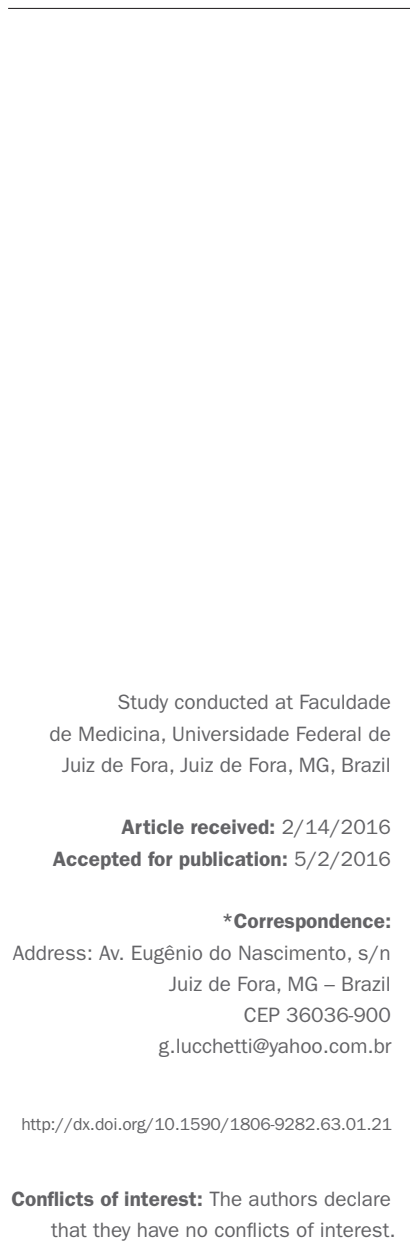

\section{SUMMARY}

Objective: To compare the prevalence of anxiety, depression, and stress in medical students from all semesters of a Brazilian medical school and assess their respective associated factors.

Method: A cross-sectional study of students from the twelve semesters of a Brazilian medical school was carried out. Students filled out a questionnaire including sociodemographics, religiosity (DUREL - Duke Religion Index), and mental health (DASS-21 - Depression, Anxiety, and Stress Scale). The students were compared for mental health variables (Chi-squared/ANOVA). Linear regression models were employed to assess factors associated with DASS- 21 scores.

Results: 761 (75.4\%) students answered the questionnaire; 34.6\% reported depressive symptomatology, $37.2 \%$ showed anxiety symptoms, and $47.1 \%$ stress symptoms. Significant differences were found for: anxiety - ANOVA: $[\mathrm{F}=2.536$, $\mathrm{p}=0.004]$ between first and tenth $(\mathrm{p}=0.048)$ and first and eleventh $(\mathrm{p}=0.025)$ semesters; depression - ANOVA: $[\mathrm{F}=2.410, \mathrm{p}=0.006]$ between first and second semesters $(\mathrm{p}=0.045)$; and stress - ANOVA: $[\mathrm{F}=2.968, \mathrm{p}=0.001]$ between seventh and twelfth $(\mathrm{p}=0.044)$, tenth and twelfth $(\mathrm{p}=0.011)$, and eleventh and twelfth $(\mathrm{p}=0.001)$ semesters. The following factors were associated with (a) stress: female gender, anxiety, and depression; (b) depression: female gender, intrinsic religiosity, anxiety, and stress; and (c) anxiety: course semester, depression, and stress. Conclusion: Our findings revealed high levels of depression, anxiety, and stress symptoms in medical students, with marked differences among course semesters. Gender and religiosity appeared to influence the mental health of the medical students.

Keywords: medical education, depression, anxiety, stress, medical students.

\section{INTRODUCTION}

University life during medical training entails full-time commitment and responsibility of undergraduates regarding academic tasks and care provided to patients and their companions. Long working and study hours, environments not ideally suited to learning, sleep deprivation, as well as factors interfering in everyday personal life are common during this period. ${ }^{1}$ These aspects, associated with a lack of factors promoting quality of life, can lead to stress levels that negatively impact the physical, mental, and emotional health of students, compromising their academic performance. ${ }^{2}$

Emotional disorders in medical undergraduates are not uncommon, influencing mental health as well as hon- esty, academic performance, and use of alcohol and other drugs. ${ }^{3}$ In Europe, around 30\% of medical students suffer from depression or anxiety, ${ }^{4}$ a rate similar to that reported by Brazilian studies, in which 20 to $50 \%$ of medical students were found to present with mood disorders. ${ }^{5,6}$ Medical students also have higher rates of depression and suicidal ideation than the general population, posing a major challenge to the training of future physicians. ${ }^{2}$

Further studies elucidating the factors associated with mental disorders that affect performance and quality of life of undergraduate medical students are needed. Within this context, stress plays a major role in this interrelationship, most likely stemming from the frequent 
exposure to pain, suffering and death. ${ }^{7}$ The high levels of stress in medical students are important predictors of anxiety and depression. ${ }^{8,9}$

In fact, health, work and quality of life are intrinsically linked, where higher levels of stress lead to a decline in quality of life due to demotivation, irritation, depression, and unhappy personal life, impacting interaction of the individuals at different points in their life. ${ }^{10}$ Thus, stress impairs learning, since this directly interferes in the brain's executive functions and can affect the performance of undergraduate students at specific times or throughout their academic course. ${ }^{11}$

In this respect, there appears to be a relationship between the course year and severity of mental disorders. ${ }^{12}$ In a four-year cohort study, mild-to-moderate depression rose from 4 to $12 \%$ during medical school training. Similarly, another study ${ }^{13}$ reported an increase in mild depression from 4.3 to $11.2 \%$, and in moderate depression from 1.7 to $6.9 \%$, by the end of the first year of medical school.

Ascertaining the times during which students are most susceptible to psychiatric disturbances may help in the implementation of strategies to promote physical, mental, emotional, and spiritual well-being. These strategies might include both individuals and the group as a whole, ${ }^{14,15}$ promoting the resumption of healthy habits, and attention to health, leisure, and religiosity. ${ }^{16-18}$

The objective of the present study was to compare the prevalence of anxiety, depression, and stress in medical students from all semesters of medical school training and assess their respective associated factors to evaluate potential stressors and identify the major challenges faced by the students during medical training. Ultimately, the results can aid in the planning and development of more effective intervention and prevention programs and in the implementation of more balanced medical curricula. ${ }^{19}$

\section{Method}

\section{Study design and participants}

This cross-sectional study included students from the six years of the medical course of the Federal University of Juiz de Fora (Brazil) and was conducted between September and November 2014. The medical course spans six years (comprising twelve separate semesters) typically divided into three stages, each averaging two years: pre-clinical, clinical, and internship.

All students officially enrolled in the medical course were invited to take part. Students away from the city of Juiz de Fora on governmental international exchange programs Sciences Without Borders or undertaking optional internships, individuals not present at the time of data collection, and those who did not complete the questionnaire or refused to take part in the study were excluded.

The project was approved by the Research Ethics Committee of the University Teaching Hospital/UFJF under report $\mathrm{n}^{\circ} 790.822$ and all participating students signed the informed consent form.

\section{Instruments}

The self-report questionnaire employed took approximately 20 minutes to answer and collected data on:

- Sociodemographics: age, ethnicity/race, marital status, employment status, family income.

- Religiosity: the Duke Religion Index was used, a five-item measure of three different dimensions of religious involvement: one question (with six possible answers) for organizational religiousness (OR)-religious attendance; one question (with six possible answers) for non-organizational religiousness (NOR) - religious activities performed in private, such as prayer, Scripture study, watching religious TV or listening to religious radio, and three questions (with five possible answers each) for intrinsic religiousness (IR) - pursuing religion as an ultimate end in itself. For the intrinsic religiosity score, we summed the three questions (possible score 3 to 15), in which higher scores indicate higher levels of religiosity. This scale has been previously validated for use in Brazil. ${ }^{20}$

- Depression, anxiety, and stress: assessed by the DASS 21 - Depression, Anxiety and Stress Scale validated for Portuguese. ${ }^{21}$ This 21 -item short scale allows simultaneous assessment of the three emotional states of depression, anxiety, and stress, is easy to apply in both clinical and non-clinical settings, and suitable for use in different age groups ${ }^{21}$ including medical students.

\section{Procedures}

Data collection took place during class time (before or after educational activities) and the questionnaire was applied as follows: the researchers explained the objectives of the study, asked students to fill out the questionnaire and sign the consent form, and guaranteed confidentiality of the data. The questionnaires were applied mid-way through the academic semester in order to assess students at a time nearest their basal state, i.e. outside exam time (end of semester) and resumption of classes (beginning of semester). 


\section{Statistical analysis}

The data collected were keyed into Excel for Windows and statistical analysis was carried out using the software package SPSS version 17.0 (SPSS Inc.). Descriptive analysis with measurements of frequency, mean, and standard deviation was used to express sociodemographic variables and results from the scales and questionnaires.

The students from the 12 semesters of the course were compared for demographic, socioeconomic, and mental health variables using the Chi-squared or ANOVA tests. When significant difference was detected by ANOVA, a post-hoc test (Bonferroni) was performed.

Linear regression models were employed to assess the factors associated with each dependent variable (stress, depression, and anxiety), including goodness-of-fit measures and assessment of $\mathrm{R}^{2}$. The following variables were entered in each step:

- Model 1: gender, semester, age, family income, organizational religiosity, non-organizational religiosity, and intrinsic religiosity.

- Model 2: DASS Depression, DASS anxiety or DASS Stress according to the dependent variable.

A value of $\mathrm{p}<0.05$ and confidence interval of $95 \%$ were adopted for all analyses.

\section{RESULTS}

Of the total 1,009 students enrolled at the medical course, $75.4 \%(n=761)$ answered the questionnaire, comprising 298 (39.1\%) at pre-clinical, 244 (32\%) at clinical, and 219 $(28,7 \%)$ at internship stages.

The profile of the sample studied was predominantly women $(55.8 \%)$ with a mean age of $22.1(\mathrm{SD}=3.3)$ years, white $(75.7 \%)$, and with a family income of > eight Brazilian minimum wages (> US\$ 2,000.00) (50.7\%). With regard to religious aspects, $51.2 \%$ of the students reported being Catholics, $17.1 \%$ no religion, $11 \%$ Evangelical or Protestant, $8.3 \%$ Spiritists, and $6.4 \%$ stated they did not believe in God. Sociodemographic data for the sample are given in Table 1.

With regard to the prevalence of depression, anxiety, and stress, as assessed by the DASS-21,34.6\% had depressive symptomatology ( $8.8 \%$ severe or extremely severe), $37.2 \%$ had anxiety symptoms (12.2\% severe or extremely severe), and $47.1 \%$ had stress symptoms (17.4\% severe or extremely severe). The constructs anxiety, depression, and stress were highly correlated, with values ranging from $\mathrm{r}=0.554$ to $0.696(\mathrm{p}<0.01)$.
TABLE 1 Sociodemographic and religious characteristics of medical undergraduate students.

\begin{tabular}{|c|c|}
\hline Variable & \\
\hline \multicolumn{2}{|l|}{ Gender (n, \%) } \\
\hline Female & $425(55.8 \%)$ \\
\hline Male & $336(44.2 \%)$ \\
\hline Age (Mean, SD) & $22.10(3.34)$ \\
\hline \multicolumn{2}{|l|}{ Stage of course $(n, \%)$} \\
\hline Pre-clinical $\left(1^{\text {st }}-4^{\text {th }}\right)$ & $298(39.1 \%)$ \\
\hline Clinical $\left(5^{\text {th }}-8^{\text {th }}\right)$ & $244(32 \%)$ \\
\hline Internship $\left(9^{\text {th }}-12^{\text {th }}\right)$ & $219(28.7 \%)$ \\
\hline \multicolumn{2}{|l|}{ Ethnicity/Race (n, \%) } \\
\hline White & $576(75.7 \%)$ \\
\hline Black & $32(4.2 \%)$ \\
\hline Mulatto & $61(8 \%)$ \\
\hline Others & $92(12.1 \%)$ \\
\hline \multicolumn{2}{|l|}{ Family income (n, \%) } \\
\hline Up to 3 minimum wages & $105(13.8 \%)$ \\
\hline 4-7 minimum wages & $261(34.3 \%)$ \\
\hline $8-12$ minimum wages & $207(27.2 \%)$ \\
\hline$>12$ minimum wages & $179(23.5 \%)$ \\
\hline Not reported & $1(0.1 \%)$ \\
\hline \multicolumn{2}{|l|}{ Religious affiliation (n, \%) } \\
\hline None, but believe in God & $130(17.1 \%)$ \\
\hline None, and do not believe in God & $49(6.4 \%)$ \\
\hline Roman Catholic & $390(51.2 \%)$ \\
\hline Evangelical/Protestant & $84(11.1 \%)$ \\
\hline Spiritist & $63(8.3 \%)$ \\
\hline Others & $27(3.5 \%)$ \\
\hline Not reported & $18(2.4 \%)$ \\
\hline
\end{tabular}

Figure 1 (A to C) shows the differences in mean depression, anxiety, and stress for the different semesters. Significant differences in means were detected for:

a. anxiety - ANOVA: $F(11,743)=2.536, p=0.004$, between first and tenth $(\mathrm{p}=0.048)$, and first and eleventh $(p=0.025)$ semesters;

b. depression - ANOVA: $F(11,745)=2.410$, $p=0.006$, between first and second semesters $(\mathrm{p}=0.045)$;

c. stress - ANOVA: $F(11,744)=2.968, p=0.001$, between seventh and twelfth $(\mathrm{p}=0.044)$, tenth and twelfth $(\mathrm{p}=0.011)$, and eleventh and twelfth $(\mathrm{p}=0.001)$ semesters.

Linear regression (Table 2) revealed associations between DASS-21 scores for:

- DASS Stress: with female gender $(B=0.87, \mathrm{SE}: 0.24$, $\mathrm{p}<0.001)$, DASS Anxiety (B=0.63, SE: 0.03, $\mathrm{p}<0.001)$ and DASS Depression ( $B=0.40$, SE: 0.03, $\mathrm{p}<0.001)-\mathrm{R}^{2}=0.568$; 
TABLE 2 Linear regression analysis of association of DASS scores with sociodemographic, religiousness, and mental health among medical undergraduate students.

\begin{tabular}{|c|c|c|c|c|c|c|}
\hline & Mode & & & Mod & & \\
\hline Stress $^{\mathrm{a}}$ & B & SE & $\mathbf{p}$ & B & SE & $\mathbf{p}$ \\
\hline Gender (female) & 1.46 & 0.37 & $<0.001$ & 0.87 & 0.24 & $<0.001$ \\
\hline Semester & -0.04 & 0.06 & 0.472 & 0.05 & 0.04 & 0.220 \\
\hline Age & 0.005 & 0.06 & 0.941 & -0.02 & 0.04 & 0.543 \\
\hline Family income & -0.05 & 0.17 & 0.770 & 0.08 & 0.11 & 0.456 \\
\hline Religious attendance & 0.15 & 0.18 & 0.394 & 0.03 & 0.12 & 0.775 \\
\hline Non-organizational religiousness & -0.18 & 0.14 & 0.186 & -0.07 & 0.09 & 0.411 \\
\hline Intrinsic religiousness & 0.03 & 0.08 & 0.677 & -0.06 & 0.05 & 0.253 \\
\hline DASS Anxiety & & & & 0.63 & 0.03 & $<0.001$ \\
\hline DASS Depression & & & & 0.40 & 0.03 & $<0.001$ \\
\hline Depression $^{b}$ & B & SE & $\mathbf{p}$ & B & SE & $\mathbf{p}$ \\
\hline Gender (female) & 0.24 & 0.32 & 0.459 & 0.56 & 0.24 & 0.023 \\
\hline Semester & -0.44 & 0.05 & 0.412 & 0.07 & 0.04 & 0.870 \\
\hline Age & 0.74 & 0.05 & 0.190 & 0.07 & 0.04 & 0.094 \\
\hline Family income & -0.16 & 0.15 & 0.281 & -0.11 & 0.11 & 0.328 \\
\hline Religious attendance & 0.08 & 0.16 & 0.599 & -0.01 & 0.122 & 0.891 \\
\hline Non-organizational religiousness & -0.16 & 0.12 & 0.191 & -0.06 & 0.09 & 0.476 \\
\hline Intrinsic religiousness & -0.23 & 0.07 & 0.001 & -0.22 & 0.05 & $<0.001$ \\
\hline DASS Stress & & & & 0.40 & 0.03 & $<0.001$ \\
\hline DASS Anxiety & & & & 0.27 & 0.04 & $<0.001$ \\
\hline Anxiety ${ }^{c}$ & B & SE & $\mathbf{p}$ & B & SE & $\mathbf{p}$ \\
\hline Gender (female) & 0.78 & 0.28 & 0.007 & 0.10 & 0.20 & 0.611 \\
\hline Semester & -0.12 & 0.04 & 0.011 & -0.94 & 0.03 & $<0.001$ \\
\hline Age & 0.001 & 0.05 & 0.978 & -0.01 & 0.03 & 0.684 \\
\hline Family income & -0.11 & 0.13 & 0.407 & -0.05 & 0.09 & 0.535 \\
\hline Religious attendance & 0.13 & 0.14 & 0.331 & 0.05 & 0.10 & 0.584 \\
\hline Non-organizational religiousness & -0.07 & 0.11 & 0.524 & 0.04 & 0.07 & 0.598 \\
\hline Intrinsic religiousness & 0.000 & 0.06 & 1.000 & -0.05 & 0.04 & 0.193 \\
\hline DASS Stress & & & & 0.18 & 0.03 & $<0.001$ \\
\hline DASS Depression & & & & 0.43 & 0.02 & $<0.001$ \\
\hline
\end{tabular}

Model 1: $R$ square $=0.030 ;$ Model $2:$ square $=0.516$

${ }^{b}$ Model 1: $R$ square $=0.036$; Model $2: R$ square $=0.446$

'Model 1: $R$ square $=0.020$; Model 2: $R$ square $=0.568$.

- DASS Depression: with female gender $(B=0.56$, SE: 0.24, $\mathrm{p}=0.023)$, intrinsic religiosity $(\mathrm{B}=0.22$, SE: $0.05, \mathrm{p}<0.001)$, DASS Anxiety ( $B=0.27$, SE: 0.04, $\mathrm{p}<0.001)$, and DASS Stress $(B=0.40$, SE: 0.03, $\mathrm{p}<0.001)-\mathrm{R}^{2}=0.446$;

- DASS Anxiety: with semester of course $(B=-0.94, \mathrm{SE}$ : $0.03, p<0.001)$, DASS Depression ( $B=0.43$, SE: 0.02, $\mathrm{p}<0.001)$ and DASS Stress $(B=0.18$, SE: 0.03, $\mathrm{p}<0.001)$ $-\mathrm{R}^{2}=0.516$.

\section{Discussion}

The results of this study revealed a high prevalence of anxiety, depression, and stress among medical students, with statistically significant differences for course semesters, and the influence of several factors such as gender and religiosity on the students' emotional state. Medical schools are known to be environments associated with stressors and factors that negatively impact academic performance as well as both physical and emotional health of students. ${ }^{9,22,23}$

With regard to the changes in mental health found for the different semesters, students from the first semester commenced activities with a high level of anxiety, exceeding that of students from the tenth and eleventh semesters, most likely stemming from the experience of 
the unknown, from the expectations of embarking on this new path, and from moving away from home (as it happens to most students in our university). Miller et al., ${ }^{24}$ investigating first-year students, postulated that stress in this group stemmed from the nature and overload of the work inherent to the medical course, as well as from the academic structure of the course and its teaching methods. In fact, embarking on a medical course is fraught with numerous challenges beginning with the selection process, undeniably competitive and with a high cut-off point, particularly at Brazilian public institutions. On top of this, there is a certain glamour conferred by society to undergraduate medical students grounded in the dream of implicit economic success, which could lead to an overexpectation and frustration. ${ }^{25}$ This phenomenon has been corroborated by various studies. ${ }^{6,26} \mathrm{~A}$ study conducted in Brazil found a higher prevalence of anxiety symptoms in first-year $(30.8 \%)$ medical students compared to sixth-year $(9.4 \%)$ medical students, ${ }^{6}$ while an investigation in Malaysia showed that anxious symptomatology was much more prevalent than depressive symptoms, and that stress in students newly enrolling in medical school was greater than students at the latter stages of the course. ${ }^{27}$

Regarding depressive symptoms, it is noteworthy that students in the present study exhibited a sharp rise in the second period of the course compared with the first. At the outset of the first year, we believe two contradictory feelings come to the fore in the students: on the one hand there is the euphoria of approval, reinforcing the dream of the chosen profession, while on the other there is the frustration of commencing a course with an eminently theoretical content and few practical activities, closely resembling the recently experienced middle school education. The introjected and oft replicated discourse that being a physician demands the abdication of social and personal life, and multiple sacrifices can exacerbate this initial discomfort. ${ }^{28}$ Similar data was found by Wolf et al ${ }^{29}$ with reports that first-year students complained of the scant opportunities to pursue their personal relationships. The authors also revealed that, at the end of the first year, students presented more depressive symptoms, which peaked at the end of the second year in the fourth semester. Similarly, Quince et al..$^{30}$ performed a longitudinal study at a UK medical school and found a prevalence of depression ranging from 5.7 to $10.6 \%$ in students on the basic years and 2.7 to $8.2 \%$ in students on the clinical stages of the course.

In the present sample, the high levels of stress across all semesters of the course are illustrated in Figure 1, with a notable rise during the eighth semester of the fourth year, marking the end of the pre-clinical stage (entry to the clinical or internship/clerkship stage), and during the twelfth period prior to graduation. A substantial decline in stress can also be noted in the tenth and eleventh semesters. During the twelfth semester, the final semester before graduation, the students normally prepare for course conclusion and assume the commitment of practicing the profession. This period is marked by the phase of preparing for the medical residency tests in the chosen area of specialization, where the selection processes are highly competitive and the residency positions are in short supply. The increased distress and lack of time, coupled with the conflicts of choosing a specialty, explain the predominance of stress in internship candidates, a situation confirmed by other authors. ${ }^{31} \mathrm{~A}$ study in three British universities involving fourth-year medical students found a $31.2 \%$ prevalence of emotional disturbances, a similar rate to those found in American studies. ${ }^{8}$ Stress was also found to correlate with depression and anxiety, showing the inter-dependence of these symptoms.

With regard to the factors associated with the mental health of these students, there was an association of gender with both depression and stress. Studies show that women have a greater prevalence of depression and anxiety in the general population, although data for medical students are conflicting. Notwithstanding, a systematic review ${ }^{3}$ revealed that half of the studies published involving medical students reported difference in depression and stress between genders, corroborated by the present findings.

Another associated factor was intrinsic religiosity. Although many studies point to an association of religious/ spiritual beliefs with mental health, physical health, and quality of life $\mathrm{f}^{32,33}$ and other investigations have assessed religiosity and medical students' views on this issue, ${ }^{34}$ few studies have specifically investigated the association between mental health and beliefs in medical education. Wachholtz et al. ${ }^{35}$ assessed 259 American medical students and found that individuals with lower levels of spiritual well-being and daily spiritual experiences had greater psychological stress and burnout. Similarly, Vasegh et al. ${ }^{36}$ found a negative correlation among religiosity, depression, and anxiety in 285 Iranian students, which is in accordance to our findings. By contrast, Lupo et al. ${ }^{37}$ conducted a study of 119 medical students in Israel and found no association between religiosity, depression, and anxiety showing these results can be reduced or augmented according to culture and religious affiliation.

The present study has several limitations. This was a cross-sectional study, thereby precluding conclusions on causality and weakening the comparison among semesters, since these involved different student groups. However, 


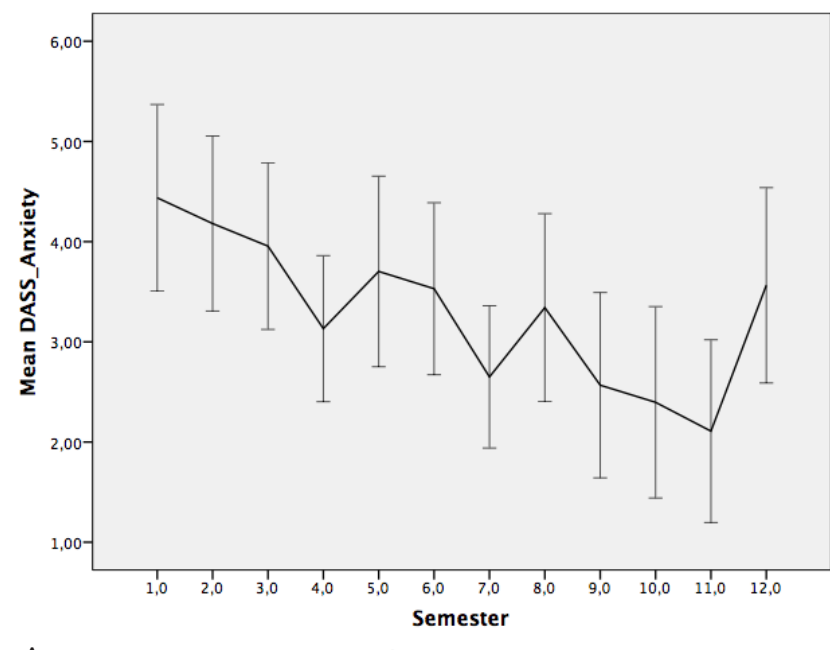

A

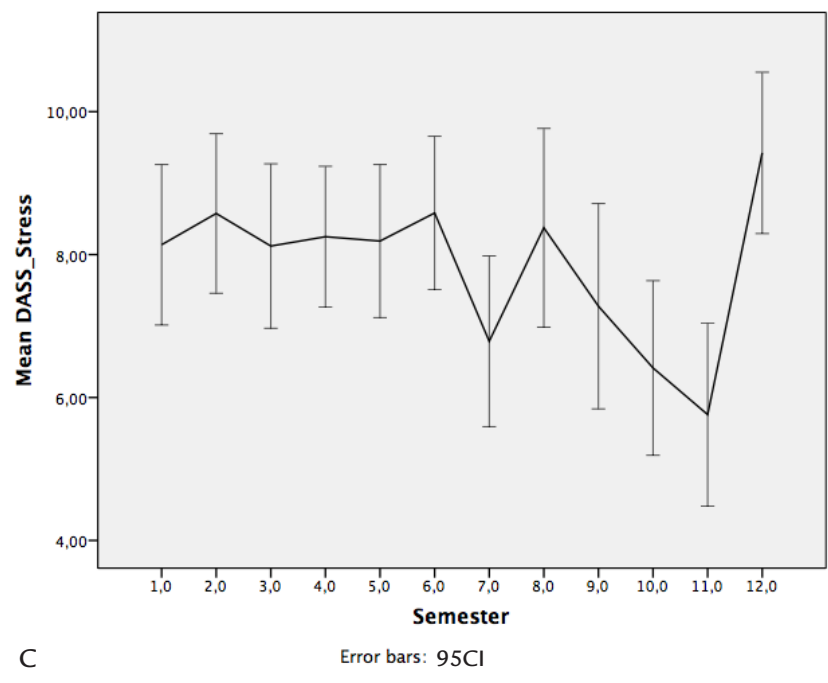

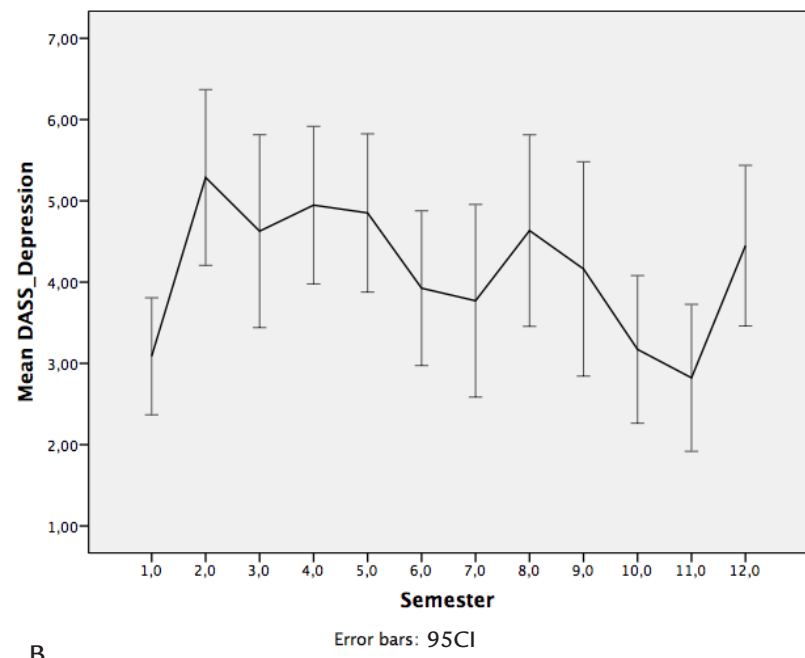

FIGURE 1 Means for (A) anxious, (B) depressive, and (C) stress symptoms from different course semesters among medical undergraduate students. A. ANOVA: $F(11,743)=2.536, p=0.004 ; 1 \times 10-$ $p=0.048 ; 1 \times 11-p=0.025$. B. ANOVA: $F(11,745)=2.414, p=0.006$; $1 \times 2-p=0.045$. C. ANOVA: $F(11,744)=2.968, p=0.001 ; 7 \times 12$ $p=0.044 ; 10 \times 12-p=0.011 ; 11 \times 12-p=0.001$.

The present study's findings revealed high levels of depressive, anxiety, and stress symptoms in medical students, with marked differences for course semesters. Factors such as gender and religiosity appeared to influence the mental health of the medical students. These results may help in devising preventive strategies and early identification of students at risk for mental health decline during the course of medical training.

\section{Conflict of interest}

The authors declare no conflict of interest.

\section{Resumo}

Objetivo: Comparar a prevalência de ansiedade, depressão e estresse em estudantes de todos os períodos de graduação de medicina e avaliar os fatores associados. 
Método: Estudo transversal e comparativo, realizado com alunos dos seis anos (doze semestres) de um curso de medicina brasileiro. Os alunos preencheram um questionário com dados sociodemográficos e relacionados à religiosidade (Duke Religion Index) e à saúde mental (DASS-21 - Depression, Anxiety and Stress Scale). Os estudantes dos 12 períodos do curso foram comparados quanto às variáveis demográficas, socioeconômicas e saúde mental por meio dos testes de Qui-quadrado ou ANOVA. Para avaliar os fatores associados a cada variável dependente (estresse, depressão e ansiedade), foram utilizados modelos de regressão linear.

Resultados: Responderam ao questionário 743 (73,63\%) dos 1.009 estudantes matriculados no curso de medicina, com $34,6 \%$ apresentando sintomatologia depressiva; $37,2 \%$, sintomas de ansiedade; e 47,1\%, estresse. Houve diferenças significantes entre os períodos em relação à ansiedade ANOVA: $(F=2,536 ; p=0,004)$, sendo as diferenças entre o primeiro e o décimo período $(\mathrm{p}=0,048)$ e entre o primeiro e o décimo primeiro período $(\mathrm{p}=0,025)$; à depressão ANOVA: $(\mathrm{F}=2,410 ; \mathrm{p}=0,006)$, sendo as diferenças entre o primeiro e o segundo período ( $\mathrm{p}=0,045)$; e ao estresse - ANOVA: $(\mathrm{F}=2,968 ; \mathrm{p}=0,001)$, sendo as diferenças entre o sétimo e o décimo segundo período $(\mathrm{p}=0,044)$, entre o décimo e o décimo segundo $(\mathrm{p}=0,011)$ e entre o décimo primeiro e o décimo segundo $(\mathrm{p}=0,001)$. Estiveram associados (a) ao estresse: gênero feminino, ansiedade e depressão; (b) à depressão: gênero feminino, religiosidade intrínseca, ansiedade e estresse; (c) à ansiedade: semestre do curso, depressão e estresse.

Conclusão: Os achados do presente estudo mostram altos níveis de sintomas de depressão, ansiedade e estresse em estudantes de medicina, com diferenças marcantes nos diferentes semestres do curso. Fatores como gênero e religiosidade parecem influenciar a saúde mental dos estudantes de medicina.

Palavras-chave: educação médica, depressão, ansiedade, estresse, estudantes de medicina.

\section{References}

1. Ghodasara SL, Davidson MA, Reich MS, Savoie CV, Rodgers SM. Assessing student mental health at the Vanderbilt University School of Medicine. Acad Med. 2011; 86(1):116-21.

2. Dyrbye LN, Thomas MR, Shanafelt TD. Medical student distress: causes, consequences, and proposed solutions. Mayo Clinic Proc. 2005; 80(12):1613-22.

3. Dyrbye LN, Thomas MR, Shanafelt TD. Systematic review of depression, anxiety, and other indicators of psychological distress among US and Canadian medical students. Acad Med. 2006; 81(4):354-73.
4. Haldorsen H, Bak NH, Dissing A, Petersson B. Stress and symptoms of depression among medical students at the University of Copenhagen. Scand J Public Health. 2014; 42(1):89-95.

5. de Rezende CHA, Abrão CB, Coelho EP, da Silva Passos LB. Prevalência de sintomas depressivos entre estudantes de medicina da Universidade Federal de Uberlândia. Rev Bras Educ Med. 2008; 32(3):315-23.

6. Bassols AM, Okabayashi LS, Silva ABd, Carneiro BB, Feijó F, Guimarães GC et al. First- and last-year medical students: is there a difference in the prevalence and intensity of anxiety and depressive symptoms? Rev Bras Psiquiatr. 2014; 36(3):233-40.

7. Lee J, Graham AV. Students' perception of medical school stress and their evaluation of a wellness elective. Med Educ. 2001; 35(7):652-9.

8. Firth J. Levels and sources of stress in medical students. BMJ. 1986; 292(6529):1177-80.

9. Saravanan C, Wilks R. Medical students' experience of and reaction to stress: the role of depression and anxiety. Scientific World Journal. 2014; 2014:737382.

10. Meyer C, Guimaraes ACA, Machado Z, Parcias SR. Qualidade de vida e estresse ocupacional em estudantes de medicina. Rev Bras Educ Med. 2012; 36(4):489-98.

11. Wolf TM. Stress, coping and health: enhancing well-being during medical school. Med Educ. 1994; 28(1):8-17; discussion 55-7.

12. Clark DC, Zeldow PB. Vicissitudes of depressed mood during four years of medical school. JAMA. 1988; 260(17):2521-8.

13. Rosal MC, Ockene IS, Ockene JK, Barrett SV, Ma Y, Hebert JR. A longitudinal study of students' depression at one medical school. Acad Med. 1997; 72(6):542-6.

14. Tempski P, Bellodi PL, Paro HB, Enns SC, Martins MA, Schraiber LB. What do medical students think about their quality of life? A qualitative study. BMC Med Educ. 2012; 12:106.

15. Jamali A, Tofangchiha S, Jamali R, Nedjat S, Jan D, Narimani A, et al. Medical students' health-related quality of life: roles of social and behavioural factors. Med Educ. 2013; 47(10):1001-12.

16. Weiner EL, Swain GR, Wolf B, Gottlieb M. A qualitative study of physicians own wellness-promotion practices. West J Med. 2001; 174(1):19-23.

17. Shapiro SL, Shapiro DE, Schwartz GE. Stress management in medical education: a review of the literature. Acad Med. 2000; 75(7):748-59.

18. Zonta R, Robles ACC, Grosseman S. Estratégias de enfrentamento do estresse desenvolvidas por estudantes de medicina da Universidade Federal de Santa Catarina. Rev Bras Educ Med. 2006; 30(3):147-53.

19. Guthrie E, Black D, Shaw C, Hamilton J, Creed F, Tomenson B. Embarking upon a medical career: psychological morbidity in first year medical students. Med Educ. 1995; 29(5):337-41.

20. Lucchetti G, Granero Lucchetti AL, Peres MF, Leão FC, Moreira-Almeida A Koenig HG. Validation of the duke religion index: DUREL (Portuguese version). J Religion Health. 2012; 51(2):579-86.

21. Vignola RCB, Tucci AM. Adaptation and validation of the depression, anxiety and stress scale (DASS) to Brazilian Portuguese. J Affect Disord. 2014; 155(1):104-9.

22. Miletic V, Lukovic JA, Ratkovic N, Aleksic D, Grgurevic A. Demographic risk factors for suicide and depression among Serbian medical school students. Soc Psychiatry Psychiatr Epidemiol. 2015; 50(4):633-8.

23. Villanueva T, Haivas I. Studying medicine and quality of life. Student BMJ. 2006; 14:133-76

24. Miller P, Surtees P. Psychological symptoms and their course in first-year medical students as assessed by the Interval General Health Questionnaire (I-GHQ). Br J Psychiatry. 1991; 159(2):199-207.

25. Quintana AM, Rodrigues AT, Arpini DM, Bassi LA, Cecim PS, Santos MS A angústia na formação do estudante de medicina. Rev Bras Educ Med. 2008; 32(1):7-14.

26. Verger P, Combes JB, Kovess-Masfety V, Choquet M, Guagliardo V, Rouillon $\mathrm{F}$, et al. Psychological distress in first year university students: socioeconomic and academic stressors, mastery and social support in young men and women. Soc Psychiatry Psychiatr Epidemiol. 2009; 44(8):643-50.

27. Yusoff MSB, Abdul Rahim AF, Baba AA, Ismail SB, Mat Pa MN, Esa AR. Prevalence and associated factors of stress, anxiety and depression among prospective medical students. Asian J Psychiatry. 2013; 6(2):128-33.

28. Benevides-Pereira A, Gonçalves MB. Transtornos emocionais e a formação em Medicina: um estudo longitudinal. Rev Bras Educ Med. 2009; 33(1):10-23.

29. Wolf T, Almen T, Faucett J, Randall H, Franklin F. Psychosocial changes during the first year of medical school. Med Educ. 1991; 25(3):174-81. 
30. Quince TA, Wood DF, Parker RA, Benson J. Prevalence and persistence of depression among undergraduate medical students: a longitudinal study at one UK medical school. BMJ Open. 2012; 2(4):e001519.

31. Millan LR, Rossi E, De Marco OLN. O suicídio entre estudantes de medicina Rev Hosp Clin Fac Med Univ São Paulo. 1990; 45(3):145-9.

32. Lucchetti G, Lucchetti AL. Spirituality, religion, and health: over the last 15 years of field research (1999-2013). Int J Psychiatry Med. 2014; 48(3):199-215.

33. Moreira-Almeida A, Koenig HG, Lucchetti G. Clinical implications of spirituality to mental health: review of evidence and practical guidelines. Rev Bras Psiquiatr. 2014; 36(2):176-82.
34. Lucchetti G, de Oliveira LR, Koenig HG, Leite JR, Lucchetti AL.; SBRAME Collaborators. Medical students, spirituality and religiosity--results from the multicenter study SBRAME. BMC Med Educ. 2013; 13:162.

35. Wachholtz A, Rogoff M. The relationship between spirituality and burnout among medical students. J Contemp Med Educ. 2013; 1(2):83-91.

36. Vasegh S, Mohammadi MR. Religiosity, anxiety, and depression among a sample of Iranian medical students. Int J Psychiatry Med. 2007; 37(2):213-27.

37. Lupo MK, Strous RD. Religiosity, anxiety and depression among Israeli medical students. Isr Med Assoc J. 2011; 13(10):613-8. 